Hulchiy O. ${ }^{1}$, Slabkiy G. ${ }^{2}$, Balashov K. ${ }^{1}$

\title{
Evidence-based approaches to communication of non-communicable diseases risks in Ukraine: identification of channels
}

\author{
${ }^{1}$ Shupyk National Medical Academy of Postgraduate Education, Kyiv, Ukraine \\ ${ }^{2}$ Uzhhorod National University, Faculty Of Medicine, Department of Public Health, Uzhhorod, Ukraine
}

kostyantyn.balashov@gmail.com

\author{
Гульчій О.П. ${ }^{1}$, Слабкий Г.О. ${ }^{2}$, Балашов К.В. ${ }^{1}$ \\ Доказові підходи до комунікації у сфері \\ неінфекційних захворювань: визначення каналів \\ ${ }^{1}$ Національна медична академія післядипломної освіти \\ імені П.Л. Шупика, м. Київ, Україна \\ ${ }^{2}$ Ужгородський національний університет, \\ м. Ужгород, Україна
}

Гульчий О.П. ${ }^{1}$, Слабкий Г.А. ${ }^{2}$, Балашов К.В. ${ }^{1}$ Доказательные подходы к коммуникации в сфере неинфекционных заболеваний: определение каналов ${ }^{1}$ Национальная медицинская академия последипломного образования имени П.Л. Шупика, г. Киев, Украина

${ }^{2}$ Ужгородский национальный университет, г. Ужгород, Украина

\section{Introduction}

According to the Institute for Health Metrics and Evaluation $^{1}$ approx. $40 \%$ of people aged 15 to 49 and $80 \%$ of 50-69 year olds in the world die from circulatory and respiratory diseases, malignant neoplasms and diabetes, commonly called non-communicable diseases (NCDs). In Ukraine, in the mentioned age groups, the share of deaths caused by NCDs is significantly higher than in European countries and accounts for approx. $60 \%$ and $90 \%$ respectively.

In 2015 , the mortality in the working age population due to NCDs (617 per 100 thousand population) in our country was one and a half times higher than the average for the WHO European Region (380 per 100 thousand) and more than three times - for the Scandinavian countries (186 per 100 thousand); and mortality due to coronary heart disease (CHD) (93 people per 100 thousand population from 0 to 64 years old) is 2.4 and more than 8 times higher than in the European region and the Scandinavian countries, respectively.
The most common causes of death among NCDs in people aged 15-49 years are the diseases listed in Table 1 according to the data ${ }^{1}$.

The average difference in life expectancy between women and men is 9 years, it ranges from 7 years in Kyiv, Zakarpattia and Donetsk Regions to 10 years in Zhytomyr, Kyiv, Zaporizhia and Chernihiv Regions.

The difference in mortality due to diseases of the circulatory system between men and women in 2017 ranged from 250 to 260 cases per 100 thousand population in Kyiv (705 per 100 thousand population for men and 451 per 100 thousand population for women) and in Odessa Region (814 and 555 per 100 thousand population, respectively), up to 480-510 cases per 100 thousand population in Kyiv Region (1109 and 623 per 100 thousand population, respectively) and in Chernihiv Region (1044 and 538 per 100 thousand population, respectively) areas with a national figure of 322 cases per 100 thousand population (786 and 464 per 100 thousand population, respectively).

Table 1. The Structure of Major Mortality Factors in Ukraine and the world (2017) (GBD Compare | Viz Hub)

\begin{tabular}{|l|l|c|c|}
\hline No & \multicolumn{1}{|c|}{ Mortality factor } & \multicolumn{2}{|c|}{$\begin{array}{c}\text { Share in the Structure of Mortality, \% } \\
\text { The world }\end{array}$} \\
\hline 1. & Breast cancer, respiratory cancer and other types of cancer & up to 17 & up to 14.6 \\
\hline 2. & Ischaemic heart disease & 8.5 & 10.2 \\
\hline 3. & Cirrhosis and chronic liver disease & 4.4 & 9.9 \\
\hline 4. & Cardiomyopathy and myocarditis & 0.9 & 7.0 \\
\hline 5. & Alcohol use & 1.1 & 5.2 \\
\hline 6. & Stroke & 4.8 & 4.4 \\
\hline 7. & Drug use & 1.3 & 1.5 \\
\hline 8. & Chronic obstructive pulmonary disease & 2 & 0.6 \\
\hline 9. & Diabetes Mellitus & 1.5 & 0.5 \\
\hline
\end{tabular}


Contrary to well-known stereotypes, NCDs are more widespread in low- and middle-income countries, where more than three-quarters of deaths caused by this pathology occur ${ }^{2}$. According to the WHO report in 2016, $78 \%$ of all deaths from NCDs and $85 \%$ of premature deaths of adults from NCDs occurred in low- and middle-income countries ${ }^{3}$.

Well-known behavioral (and therefore controlled) risk factors for NCDs are:

- tobacco use,

- physical inactivity,

- unhealthy diet and

- excessive alcohol consumption.

According to the WHO, tobacco products cause more than 7.2 million deaths worldwide each year. 4.1 million deaths each year are due to excess salt and sodium intake. More than 1.7 million annual NCD-related deaths occur due to alcohol abuse, 1.6 million deaths occurred due to lack of physical activity $^{2}$.

Metabolic risk factors that increase the risk of NCDs include:

- high blood pressure,

- overweight/obesity,

- hyperglycemia,

- hyperlipidemia.

In terms of mortality, the leading metabolic risk factor worldwide is high blood pressure, followed by overweight and high blood glucose level.

WHO has developed a global action plan for the prevention and control of NCDs for 2013-20204, which provided for the implementation of six tasks:

1. Raise the priority of NCDs prevention and control by strengthening international cooperation and advocacy.

2. Strengthen national capacity, leadership, governance, multi-sectoral action and partnerships.

3. Reduce the impact of managed risk factors for noncommunicable diseases and key social determinants by creating health-promoting environments.

4. Orient health care systems to ensure the prevention and control of noncommunicable diseases through primary health care and universal coverage of health services.

5. Promote and support national capacity for highquality research and development in the prevention and control of noncommunicable diseases.

6. Monitor trends and determinants of noncommunicable diseases, assess progress in their prevention and control.

Indicators of the effectiveness of the tasks were nine global goals that countries seek to achieve by $2025^{4}$, which include:

1. $25 \%$ reduction in the risk of premature death from cardiovascular diseases, cancer, diabetes or chronic respiratory diseases.

2. $10 \%$ reduction in harmful alcohol consumption.

3. $10 \%$ reduction in the prevalence of insufficient physical activity.

4. $30 \%$ reduction in average salt consumption.

5. $30 \%$ reduction in the prevalence of tobacco use among persons over 15 years of age.
6. Stabilization (and better - reduction by $25 \%$ ) of the prevalence of high blood pressure.

7. Stopping the spread of diabetes and obesity.

8. Receiving drug therapy and counseling (including glycemic control) to prevent heart attacks and strokes in at least $50 \%$ of people, who need treatment.

2. Ensuring $80 \%$ availability of basic technologies and basic medicines, including generic medicines, needed for the treatment of major non-communicable diseases in both public and private institutions.

The topic of NCDs prevention is not new for Ukraine. In recent decades, preventive measures have been mainly carried out in the direction of administrative regulation (ban on smoking in public places, increase in excise duties on alcohol and tobacco, etc.), information (media) campaigns aimed at certain risk factors, and teaching the basics of healthy living in schools. In the last few years, similar educational activities have been carried out by the Ministry of Health and the Center for Social Welfare through social media pages.

The National Action Plan on Non-communicable Diseases for Achieving the Global Sustainable Development Goals, approved by the Government of Ukraine in 2018, operates along with a wider range of information measures to prevent NCDs. The National Action Plan on Noncommunicable Diseases for Achieving the Global Sustainable Development Goals, approved by the Government of Ukraine in 2018, operates with a wider range of information measures to prevent NCDs.

Along with conducting information campaigns, raising public awareness, adapting international information materials, including audiovisual materials on the Internet, the introducing materials on NCDs prevention in curricula for schoolchildren and students, the authors of the National Plan propose to develop and implement in institutions of higher pedagogical and medical education changes to curricula aimed at improving the readiness of teachers and physicians for taking active preventive measures, to conduct thematic trainings for medical doctors and even introduce an assessment of individual risk of NCD development at the level of the first medical aid, etc. Thus, there is a certain movement from purely informational (media) methods of communication to more selective and personalized.

At the same time, the analysis of the data of the report of the Multiple Indicator Cluster Survey ${ }^{5}$ shows that health workers are the main and most trusted source of information for the population about health in Ukraine.

The resolution of the scientific \& practical conference "Prevention of Non-Communicable diseases. Medical, social and clinical aspects", which took place in Kyiv in 2018, called for paying more attention to the role of physicians in the prevention of NCDs In particular, it was proposed to ensure the implementation of cost-effective measures focused on the needs of different groups of the population, to introduce preventive counseling in primary care, to take into account NCD prevention in the development of curricula and training plans for medical doctors at medical faculties of higher education, to provide scientific support for the introduction of innovative technologies and programs for prevention and 
treatment of the most common NCDs at the primary level of medical care with the involvement of professionals from regional Public Health Centers and to provide continuous training of physicians on NCD prevention.

Dr. Jarno Habicht, WHO Representative in Ukraine, drew attention to the importance of involving medical doctors in NCD prevention: "Healthcare professionals are an important source of information, and their close relationship with a health care provider is a cornerstone of the health care system (...). We need to ensure that medical doctors and nurses have the knowledge and skills (...) [and] are able to provide evidence of key risk factors" (https://moz.gov.ua/article/news/scho-robitukraina-dlja-podolannja-neinfekcijnih-hvorob).

This quote shows that increasing the role of physicians in NCD prevention is not only a matter of changing the information channel to a more effective one, but also an opportunity to change the prevention methodology from advocacy (mostly one-way informing the public) to communication - exchange of information between medical doctor and patient.

The importance of dialogue communication as opposed to monologue informing about risks is actively discussed by the world, and in particular by the Ukrainian scientific community $^{6,7}$. Thomas Abraham, the director of the Communication Program in Health Care at the University of Hong Kong, warns against over-simplifying communication and promoting ready-made solutions instead of open inclusive dialogue: "The principle failure was this: instead of using the tools and principles of risk communication to create public understanding of the risks posed by a pandemic, experts and policy makers used another form of communication, advocacy, which is intended not so much to create understanding but to persuade the public to take certain actions"

The feasibility of greater involvement of health workers in the prevention of NCDs in Ukraine can be assessed through analyzing the characteristics of groups that trust the main channels of health information and studying their demographic, behavioral and social determinants.

Aim: to propose approaches to increase the effectiveness of communicating risks of non-communicable diseases based on the study of preferences of citizens of Ukraine the for health information channels.

\section{Materials and methods}

Based on the data of the Multi-Indicator Cluster Survey of Households (MICS-2012), which was conducted with the assistance of UNICEF, the Swiss Cooperation Office and the United States Agency for International Development ${ }^{5}$, the responses of 12068 men and women from all regions Ukraine were analyzed for:

- the frequency of receiving and the level of trusting information concerning their health received from various channels;

- the presence of links between the population's commitment to different channels of information and health factors (eg, awareness of family planning methods, children's health, NCD determinants).

Relative indicators of the prevalence of information channels and levels of trusting them were also assessed. Based on the analysis of descriptive statistics, methods of pairwise comparison with application of Bonferoni adjustment for relative terms and analysis of variance (ANOVA) for averages, statistically significant differences in health awareness are established, in particular in family planning methods, children's health, NCDs determinants in groups of respondents formed on the basis of their trusting health information sources.

Statistical processing was performed using a software package SPSS Statistics 23.

\section{Results}

Analysis of MICS-2012 data shows ${ }^{9}$ that despite the actual total coverage of the population of Ukraine by TV network and intensive internetization, only four health information channels cover more than $20 \%$ of the population and at the same time more than $10 \%$ of citizens trust them (Table 2): $81.6 \%)$

1. health workers (coverage - 85.7\%, trusting -

2. friends and relatives $(42.5 \%$ and $23.4 \%$, respectively);

3. Internet ( $31.8 \%$ and $11.1 \%$, respectively);

4. recommendations of pharmacies $(24.4 \%$ and $12.6 \%$, respectively).

Table 2. Prevalence and Trust in Source of Information on Health Related issues in Ukraine (2012)

\begin{tabular}{|c|c|c|c|c|}
\hline № & Channel & Gender & $\begin{array}{l}\text { Receiving health information } \\
\text { in recent months, \% }\end{array}$ & $\begin{array}{l}\text { Trusting the channel } \\
\text { in terms of health, \% }\end{array}$ \\
\hline \multirow[t]{2}{*}{1.} & \multirow{2}{*}{ Health workers } & female & 86.3 & 82.5 \\
\hline & & male & 74.5 & 70.2 \\
\hline \multirow[t]{2}{*}{2.} & \multirow[t]{2}{*}{ Friends/Relatives } & female & 41.2 & 21.8 \\
\hline & & male & 40.5 & 24.2 \\
\hline \multirow[t]{2}{*}{3.} & \multirow[t]{2}{*}{ Television } & female & 41.9 & 7.6 \\
\hline & & male & 29.8 & 6.0 \\
\hline \multirow[t]{2}{*}{4.} & \multirow[t]{2}{*}{ Internet } & female & 31.8 & 10.7 \\
\hline & & male & 28.1 & 10.6 \\
\hline \multirow[t]{2}{*}{5.} & \multirow{2}{*}{$\begin{array}{l}\text { Pharmacies' } \\
\text { recommedations }\end{array}$} & female & 26.2 & 13.3 \\
\hline & & male & 17.5 & 9.6 \\
\hline
\end{tabular}



6. Newspaper
7. Journals
8. Books
9. Radio

\begin{tabular}{|l|l|}
\hline female & \\
\hline male & 1 \\
\hline female & \\
\hline male & 1 \\
\hline female & \\
\hline male & \\
\hline female & \\
\hline male & \\
\hline
\end{tabular}

12.2

8.5

11.9

3.4

9.7

3.5

4.8

3.7
1.7

1.1

2.4

0.4

3.9

1.6

1.0

0.6
Effectively influencing respondents' behavior through the "friends and relatives" channel seems unlikely, television is expensive and ineffective due to its low level of trust. Thus, in establishing communication, it makes sense to focus on the network of health facilities, Internet resources and pharmacies. At the same time, the use of medical staff and pharmacy staff as a channel of information requires answers to questions about their own sources of professional health information, as well as further research. Some remarks on the study of the determinants of knowledge acquisition among physicians were made in the articles ${ }^{10,11}$.

Analysis of the study data confirmed a statistically significant relationship between adherence to a particular information channel and the level of awareness of dangerous conditions of the child, reproductive health and HIV infection prevention; demographic and cultural ${ }^{9}$ factors:

- for older married women, the preferred channels of health information are health workers, television, pharmacies' recommendations and print media (newspapers, magazines and books - especially for women with higher education);

- for people of both sexes aged 15-19 and men aged $20-49$, the recommendations of friends and relatives are more important;

- young single women with higher education living in cities prefer the Internet.

In general, women pay more attention to health information than men, regardless of the source and intensity of its use.

Statistically significant differences were found in the attitude to the signs of threat to the health or life of the child.
Respondents assessed the likelihood of seeking medical aid in case of fever, difficulty or acceleration of breathing, the presence of blood in children's stools, deterioration or disorders of fluid intake. Statistically significant differences in preference/trust levels allow us to make assumptions about the characteristics of persons loyal to each communication channel:

- people who trust the recommendations of pharmacy and health care workers are more likely to seek medical help for most reasons (aware/wary);

- those who prefer receiving information from friends are likely to have a shortage of professional information;

- those who prefer the Internet are more aware of the rare causes of disease;

- people who do not trust any of the sources are significantly less likely to seek medical care in general.

Similarly, trusting the Internet, recommendations from pharmacies and healthcare professionals is associated with higher awareness of family planning methods $(88 \%, 86.3 \%$ and $83.7 \%$ of respondents have heard about them, respectively), and reliance on friends and relatives - with lower awareness $(77.7 \%)$. A survey of men confirmed a link between trusting health workers and a higher frequency of condom use. Also, men who trust health care workers are less likely than others to put responsibility for contraception solely on women, and those who prefer pharmacies, television, and who do not trust anyone are more likely to do it.

Women's responses related to NCDs or their determinants in terms of the four largest health information channels and as well as responses of women who do not trust any channel were analyzed in detail (Table 3).

Table 3. Determinants of NCD development in women depending on the considered source of information on health related issies (for State statistics service of Ukraine, etc. 2013)

\begin{tabular}{|c|c|c|c|c|c|}
\hline & $\begin{array}{l}\text { Healthcare } \\
\text { workers }\end{array}$ & Friends & Pharmacies & Internet & $\begin{array}{l}\text { Do not trust } \\
\text { any source }\end{array}$ \\
\hline Seeked medical aid & $74.9(\uparrow)^{*}$ & 72.6 & 77.0 & 78.1 & 68.5 \\
\hline Cigarette smokers at present & $29.3(\downarrow)^{*}$ & 29.2 & 28.7 & 27.9 & $46.0(\uparrow)^{*}$ \\
\hline $\begin{array}{l}\text { Has been smoking tobacco products } \\
\text { for the last month }\end{array}$ & 20.6 & 17.0 & 25.2 & $28.7(\uparrow)^{*}$ & 16.7 \\
\hline Age of onset of smoking & $15.8^{b}$ & $15.0^{\mathrm{a}}$ & $16.4^{\mathrm{c}}$ & $15.7^{\mathrm{b}, \mathrm{c}}$ & $15.7^{\mathrm{b}, \mathrm{c}}$ \\
\hline $\begin{array}{l}\text { Number of cigarettes smoked in the } \\
\text { last } 24 \text { hours }\end{array}$ & $8.2^{\mathrm{a}, \mathrm{b}}$ & $8.2^{\mathrm{a}, \mathrm{b}}$ & $8.1^{\mathrm{a}, \mathrm{b}}$ & $7.4^{\mathrm{a}}$ & $9.2^{\mathrm{b}}$ \\
\hline $\begin{array}{l}\text { Number of smoking days in the last } \\
\text { month }\end{array}$ & $25.9^{\mathrm{a}, \mathrm{b}}$ & $25.1^{\mathrm{a}, \mathrm{b}}$ & $25.2^{\mathrm{a}, \mathrm{b}}$ & $25.1^{\mathrm{a}}$ & $27.5^{b}$ \\
\hline Age of onset of alcohol consumption & $17.0^{\mathrm{a}}$ & $16.7^{b}$ & $16.8^{b}$ & $16.8^{b}$ & $16.9^{b}$ \\
\hline
\end{tabular}


Number of days of alcohol consumption in the last month $2.4^{\mathrm{a}}$ $2.6^{\mathrm{b}, \mathrm{c}}$ $2.8^{\mathrm{c}}$ $2.4^{\mathrm{a}, \mathrm{b}}$

$*$ The statistical probability of the difference in the indicators between those who trust and those who do not trust the information channel is demonstrated $(\mathrm{p}<0.05)$.

$a, b$ Each letter indicates a group of indicators that do not differ statistically significantly.

These results show that proponents of obtaining information from physicians are more health-oriented (lower levels of smoking, higher levels of seeking medical care and higher awareness), and people who do not trust anyone pay the least attention to health issues.

At the same time, the relatively late age of smoking and alcohol use onset in groups of people who trust health workers may indicate the influence of family or social environment in childhood on the formation of such beliefs.

To better understand the structure of the audience, subgroups of respondents who trust several information channels simultaneously were analyzed. The analysis shows that most people who trust the information of friends, pharmacies and the Internet also trust health care workers, and the mutual "overlap" of other trust groups does not exceed $29 \%$. The prevalence of trusting two sources of information is as folows:

- trusting health care workers and friends: 15.4 persons out of 100 respondents;

- trusting employees of health facilities and pharmacies: 10.2 persons out of 100 respondents;

- trusting healthcare workers and the Internet: 6.3 persons out of 100 respondents;

- trusting friends and pharmacies: 3.5 persons out of 100 respondents;

- to friends and the Internet: 2.4 persons out of 100 respondents;

- to the Internet and pharmacies: 1.1 persons out of 100 respondents;

- another $2.6 \%$ trust healthcare workera, friends and pharmacies at the same time, and $1.3 \%$ trust healthcare, friends and the Internet.

\section{Discussion}

Thus, it can be argued that the target audience of these four health information channels have a significant overlap in trusting healthcare professionals, but are virtually independent of the other channels. Among those who do not trust health care workers, the most numerous groups are supporters of friends and relatives (33.3 per 100 respondents), the Internet (20.4), television (10.8) and people who do not trust any channel (20.3).

Thus, there is a need to form separate selective approaches to different groups of the target audience, the leading among which is a group of people who trust information from health workers and from the Internet. Groups of people who trust friends and relatives or do not trust any of the channels need more detailed study to develop an evidencebased communication strategy.

Training of health workers (medical doctors, nurses, public health proffessionals, etc.) for effective prevention of NCDs should be carried out in two areas:
1) professional training (WHAT to say/ask: the presence of risk factors, advice on counseling or lifestyle changes, etc.);

2) communication training (HOW to say: formulating simple and meaningful messages, defining effective individual approaches, including those related to communication tactics: in which cases it is better to ask the patient, and when to report information in the form of a statement of fact; ways of formulating a recommendation: imperative or conditional way, appropriateness of variable options, etc. Particular attention should be paid to the study of methods to improve the effectiveness of messages, including training for work with social networks or other modern technical means of communication).

Due to the specifics of NCDs, special training should be provided for primary care physicians, nurses and specialists who patients to with common pathologies or the first signs of NCDs are referred to:

- family doctors and nurses, pediatricians, stomatologists, obstetricians and gynecologists of Family Planning Centers, school nurses, etc.;

- cardiologists, neurologists, gastroenterologists, pulmonologists, endocrinologists, ophthalmologists, etc.

Thus, from the perspective continuing professional development of medical doctors, there is a need to develop a multidisciplinary certificate training, which aims at forming a common understanding of early NCDs signs, risk factors and prevention methods, as well as features of communicating risks of this group of pathologies, presenting the most common situational models and ways to achieve the required results, providing tools for monitoring and evaluation, etc. In-depth training on specific practical issues can be obtained in the form of master classes. Currently, the subject of such a training on communications in health is being developed at Shupyk National Medical Academy of Postgraduate Education (Kyiv, Ukraine).

The acquired integrated competence of medical staff, which will allow to successfully implement NCD prevention measures, is the ability to a) promptly identify relevant to a particular patient risks of NCD development; b) determine its communication features; c) provide the patient with the necessary practical advice in a form that will ensure maximum adherence under the given conditions.

A promising direction in developing systemic prevention of NCDs is a combination of the influence and authority of medical doctors and opportunities for mass communication through social networks. Professional communities or individual medical doctors can effectively implement preventive measures or monitor compliance with recommendations through social networks.

Determining the peculiarities of perception of medical information on social networks, finding out the current state of trusting health information channels and mapping the 
information field of health care workers requires more detailed research.

More research is required to study the population's need for obtaining information on prevention of NCDs, and development of mechanisms to motivate the population (in general, and among individual groups of communication impact) to obtain information on prevention of NCDs and form responsible attitude to personal health.

\section{Conclusions}

NCDs are the leading cause of morbidity and mortality in Ukraine. The determinants of these conditions are known and can be controlled, which makes the task of informing the population a priority. The main emphasis in NCDs prevention over the last decade has been made on administrative bans and media information campaigns.

Data analysis from the Multiple Indicator Cluster Survey (2012) shows that employees of health facilities have significantly more trust than friends and relatives, employees of pharmacies, the Internet and television. A comparison of public awareness of children's health, the basics of reproductive health, data on smoking and alcohol consumption shows a higher health awareness and a propensity for healthier behavior among those who trust medical doctors compared to other channels of information.

A framework for the training of medical staff on NCD prevention is proposed, which provides for the acquisition of professional and communication competencies for effective work with patients.

\section{References}

1. The Institute for Health Metrics and Evaluation (IHME). The Institute for Health Metrics and Evaluation (IHME). Published 2020. Accessed May 1, 2020. https://vizhub.healthdata.org/gbd-compare.

2. Organization WH. WHO Noncommunicable diseases. Noncommunicable diseases. Published 2020. Accessed July 1, 2020. https://www.who.int/news-room/fact-sheets/detail/noncommunicable-diseases.

3. World Health Organization. Noncommunicable Diseases Country Profiles. World Health Organization; 2018.

4. World Health Organization. Global Action Plan for the Prevention and Control of Noncommunicable Diseases $2013-$ 2020. World Health Organization; 2013.

5. Derzh. sluzhba statystyky Ukrayiny et al. Multyindykatorne Klasterne Obstezhennya Domogospodarstv. K.I.S.; 2012.

6. Voronenko Y, Hulchiy O, Khomenko I, Zakharova N, Balashov K. Komunikacijna kompetenciya yak skladova kompleksnoho navchannya fakhivciv hromadskogo zdorovya. Ukrayina Zdorovya naciyi. Published online 2017.

7. Slabkiy G, Myronyuk VI, Kachala LO. Systema hromadskogo zdorovya: bachennya Vsesvitnoyi orhanizaciyi okhorony zdorovya. Osnovni operatyvni funkciyi hromadskogo zdorovya ta yikh zmist. Ukrayina Zdorovya naciyi 2017. Published online 2017:24-31.

8. Abraham T. The price of poor pandemic communication. Br Med J. Published online 2010:1307.

9. Balashov K. Hromadske zdorovya ta kultura: tochky dotyku. In: Hromadske Zdorovya Ta Kultura: Tochky Dotyku. SSPG Publish; 2020:74-79.

10. Voronenko Y, Hulchiy O, Khomenko I, Zakharova N, Balashov K. Methods For Communication Processes Enhancement In The "Provider-Consumer (Learner)" System Of Educational Services. Wiadomości Lek. $2020 ; 8$.

11. Voronenko Y, Hulchiy O, Kharchenko N, Zakharova N, Balashov K. Dokazovo pobudovana komunikaciya: neobkhidna peredumova upravlinnya bezperervnym profesijnym rozvytkom. Ukr medychnyj chasopys. 2020;VII/VIII:1-4.

Дата надходження рукопису до редакції: 17.07.2020 p.

According to the Institute for Health Metrics and Evaluation approx. 40\% of people aged 15 to 49 and $80 \%$ of 50-69 year olds in the world die from non-communicable diseases (NCDs). In Ukraine, in the mentioned age groups, the share of deaths caused by NCDs is significantly higher than in European countries and accounts for approx. $60 \%$ and $90 \%$ respectively.

Aim. The aim of this article is to propose approaches to increase the effectiveness of communicating risks of noncommunicable diseases based on the study of preferences of citizens of Ukraine the for health information channels.

Material and methods. Data analysis from the Multiple Indicator Cluster Survey (2012) shows that employees of health facilities have significantly more trust than friends and relatives, employees of pharmacies, the Internet and television.

Results and discussion. A comparison of public awareness of children's health, the basics of reproductive health, data on smoking and alcohol consumption shows a higher health awareness and a propensity for healthier behavior among those who trust medical doctors compared to other channels of information.

Conclusions. A framework for the training of medical staff on NCD prevention is proposed, which provides for the acquisition of professional and communication competencies for effective work with patients.

Key words: public health, medical education, health communication, non-communicable diseases. 
За даними Інституту вимірювання та оцінки здоров’я бл. 40\% людей у віці від 15 до 49 та $80 \%$ у віці 50-69 років у світі помирають від неінфекційних захворювань (НІ3). В Україні у згаданих вікових групах частка смертей, спричинених НІ3, значно вища, ніж у європейських країнах, і становить близько 60\% та 90\% відповідно.

Мета. Запропонувати підходи до підвищення ефективності комунікації ризиків розвитку неінфекційних захворювань на основі вивчення вподобань громадян України щодо каналів отримання інформації про здоров'я.

Матеріали та методи. Аналіз даних Мультиіндикаторного кластерного обстеження домогосподарств (MICS-2012) показує, що працівники медичних закладів користуються істотно більшою довірою, ніж друзі та родичі, працівники аптек, інтернет та телебачення.

Результати. Порівняння обізнаності населення щодо здоров'я дітей, основ репродуктивного здоров'я, даних про куріння та вживання алкоголю свідчить про вищу інформованість щодо здоров'я та схильність до більш здорової поведінки серед тих, хто довіряє лікарям, порівняно з іншими каналами інформації.

Висновки. Запропонована рамка підготовки медичного персоналу з питань профілактики НІЗ, що передбачає опанування фахових та комунікаційних компетенцій для ефективної роботи з пацієнтами.

Ключові слова: громадське здоров'я, медична освіта, комунікація в галузі охорони здоров'я, неынфекцыйны захворювання.

По данным Института измерения и оценки здоровья около 40\% людей в возрасте от 15 до 49 и $80 \%$ в возрасте 50-69 лет в мире умирают от неинфекционных заболеваний (НИ3). В Украине в упомянутых возрастных группах доля смертей, вызванных НИЗ, значительно выше, чем в европейских странах, и составляет около $60 \%$ и $90 \%$ соответственно.

Цель. Предложить подходы к повышению эффективности коммуникации рисков развития неинфекционных заболеваний на основе изучения предпочтений граждан Украины относительно каналов получения информации о здоровье.

Материалы и методы. Анализ данных Мультииндикаторного кластерного обследования домохозяйств (MICS-2012) показывает, что работники медицинских учреждений пользуются существенно большим доверием, чем друзья и родственники, работники аптек, интернет и телевидение.

Результаты. Сравнение осведомленности населения о здоровье детей, основах репродуктивного здоровья, данных о курении и употреблении алкоголя свидетельствует о более высоком уровне информированности о здоровье и склонности к более здоровому поведению лиц, доверяющих врачам, по сравнению с теми, кто предпочитает другие каналы информации.

Выводы. Предложена рамка подготовки медицинского персонала по вопросам профилактики НИЗ, которая предусматривает овладение профессиональными и коммуникационными компетенциями для эффективной работы с пациентами.

Ключевые слова: общественное здоровье, медицинское образование, коммуникация в области здравоохранения, неинфекционные заболевания.

Конфлікт інтересів: відсутній.

Conflicts of interest: authors have no conflicts of interest to declare.

\section{Відомості про авторів}

Hulchiy Olesya - Vice-Rector for International Relations Shupyk National Medical Academy of Postgraduate Education, Kyiv, Ukraine.

ORCID ID 0000-0001-8283-8672.

Slabkiy Gennady - Faculty Of Medicine, Department of Public Health, Uzhhorod National University, Uzhhorod, Ukraine. ORCID ID 0000-0003-2308-7869.

Balashov Kostyantyn (corresponding author) - Division of Communication Shupyk National Medical Academy of Postgraduate Education; 9 Dorohozhytska str., 04112, Kyiv, Ukraine.

+380 (44) 205-48-34, kostyantyn.balashov@ gmail.com, ORCID ID 0000-0002-7820-4527. 